\title{
Breast carcinoma in young females below the age of 40 years: A histopathological perspective
}

\author{
Shitalmala Thangjam, Rajesh Singh Laishram, Kaushik Debnath
}

\begin{abstract}
Background: Breast cancer among young women is a rare pathology, but is known to have a more aggressive behavior and poorer outcome. Aims: The objective of this study was to evaluate the clinicopathological characteristics of breast carcinoma below 40 years in comparison to that over 40 years in Manipur, India. Settings and Design: This retrospective study from the period of January 2005-December 2010 was conducted in the Department of Pathology, Regional Institute of Medical Sciences, Imphal, Manipur. Materials and Methods: All cases of mastectomy specimens of carcinoma breast from the period of January 2005-December 2010 were included in the study. Clinical and histopathological data of all cases were reviewed and correlated. Results: A total of 507 mastectomy specimens were received, among which, 160 cases (31.56\%) were below 40 years; whereas 347 cases (68.44\%) were above 40 years of age. Stage III was the commonest stage (47\% versus I $8 \%$ ) in the younger group; while in the older group, Stage II was the commonest (64\% versus 34\%). Conclusion: This study shows that young females with breast cancer have higher stage of tumor.
\end{abstract}

Key words: Breast cancer, mastectomy, TNM staging of breast cancer, young, histopathology

\section{Introduction}

Breast cancers rarely occur in young women. About $2 \%$ of the patients with breast cancer are below 35 years. ${ }^{[1]}$ Breast cancer at young age has been reported to have a more aggressive behavior and unfavorable prognosis compared to the older patients. ${ }^{[1,2]}$ In breast cancer, young refers to women 40 years and below. ${ }^{[3,4]}$

In young women, the incidence of the disease is low (less than 17 cases per 100,000) women or less than $6 \%$ of all breast cancers among women of any age..$^{[5,6]}$ However, accumulating evidence suggests that breast cancer in this age group is more aggressive and associated with poorer outcome than in their older counterparts. ${ }^{[7-9]}$ Although some reports have identified young age at diagnosis as an adverse prognostic indicator ${ }^{[10]}$ this could be ascribed to a combination of factors, including delayed presentation, advanced disease stage, and unfavorable tumor characteristics. ${ }^{[11,12]}$

The objective of this study was to evaluate the clinicopathological characteristics of breast carcinoma below 40 years in comparison to older patients in Manipur, India.

\section{Materials and Methods}

This was a retrospective study done from the period of

Department of Pathology, Regional Institute of Medical Sciences,

Lamphelpat, Imphal, Manipur, India

Correspondence to: Dr. Rajesh Singh Laishram,

E-mail: rajeshlaishr@gmail.com

\begin{tabular}{|l|l|}
\hline \multicolumn{2}{|c|}{ Access this article online } \\
\hline Quick Response Code: & Website: \\
\hline & www.sajc.org \\
\hline & \\
\hline
\end{tabular}

January 2005 to December 2010 in the Department of Pathology, Regional Institute of Medical Sciences, Imphal, Manipur.

All the patients who were diagnosed as breast carcinoma and underwent mastectomy were included. All cases were reviewed and the relevant clinical data were collected and the histopathology slides were reviewed. Patients were grouped in two age groups as below and above 40 years. All data including family history, clinical presentation, pathological type, and TNM stages were compared. Exclusion criteria included (a) the patients who were diagnosed as in situ cases, (b) patients who were diagnosed as breast carcinoma on fine needle aspiration cytology, but were lost to follow up, and (c) male breast cancer. Ethical clearance from the institutional ethical committee was obtained.

The data were analyzed using tables and percentages and the results obtained formed the basis of the discussion. The outcomes of breast cancer between the two age groups were analyzed using Pearson Chi-square test with the help of the statistical software "SPSS-20".

\section{Results}

Out of the total 507 mastectomy specimens, 160 cases (31.56\%) were below 40 years and 347 (68.44\%) were above 40 years. The year-wise distribution of cases in both the groups is shown in Table 1. Ductal carcinoma was the most common tumor followed by lobular carcinoma in both age groups. The various histopathological types of tumor in both the age groups are enumerated in Table 2. Comparing the nodal involvement and the size of the tumor mass between the two age groups, we found that the younger patients had greater number of nodes involved and a larger size of the tumor mass.[Table 3]. TNM stage in both the age groups are compared and shown in Table 4. TNM stage III was the commonest stage in younger patients followed by stage II. However in contrast, older age groups showed lower stage at 
presentation with maximum cases in stage II followed by stage III.

Patients attending the Regional Cancer Center of our institute were followed-up from the case files. Out of the 507 cases, 337 cases registered and the rest of the 170 cases were lost to follow-up. The reasons for lost to follow-up could be due to poor socioeconomic

Table 1: Age grouping of female patients with breast cancer

\begin{tabular}{lcccc}
\hline $\begin{array}{l}\text { SI. } \\
\text { No. }\end{array}$ & Year & $\begin{array}{c}\text { Below 40 years } \\
(\boldsymbol{n}=\mathbf{1 6 0})\end{array}$ & $\begin{array}{c}\text { Above } \mathbf{4 0} \text { years } \\
(\boldsymbol{n}=\mathbf{3 4 7})\end{array}$ & Total \\
\hline 1 & 2005 & 27 & 54 & 81 \\
2 & 2006 & 22 & 50 & 72 \\
3 & 2007 & 36 & 61 & 97 \\
4 & 2008 & 24 & 64 & 88 \\
5 & 2009 & 24 & 53 & 77 \\
6 & 2010 & 27 & 65 & 92 \\
Total & & $160(31 \%)$ & $347(68 \%)$ & 507 \\
\hline
\end{tabular}

Table 2: Histological types of all cases

\begin{tabular}{lcc}
\hline Tumor types & $\begin{array}{c}\text { Below } \\
\text { 40 years } \\
(n=160)\end{array}$ & $\begin{array}{c}\text { Above } \\
\text { 40 years } \\
(n=347)\end{array}$ \\
\hline $\begin{array}{l}\text { Ductal carcinoma (not } \\
\text { otherwise specified (NOS)) }\end{array}$ & $137(85.62 \%)$ & $290(83.57 \%)$ \\
Lobular carcinoma & $13(8.13 \%)$ & $29(8.36 \%)$ \\
Medullary carcinoma & $5(3.12)$ & $8(2.31)$ \\
Metaplastic carcinoma & $2(1.25)$ & $6(1.73)$ \\
Malignant phylloides & $2(1.25)$ & $5(1.44)$ \\
Papillary carcinoma & $1(0.6)$ & $4(1.15)$ \\
Mucinous carcinoma & - & $3(0.86)$ \\
Malignant spindle tumor & - & $2(0.57)$ \\
\hline
\end{tabular}

Table 3: Table showing tumor size and nodal status of patients

\begin{tabular}{ccc}
\hline & $\begin{array}{c}\text { Below 40 yrs } \\
(\boldsymbol{n}=\mathbf{1 6 0})(\%)\end{array}$ & $\begin{array}{c}\text { Above } 40 \text { yrs } \\
(\boldsymbol{n}=\mathbf{3 4 7})(\%)\end{array}$ \\
\hline Tumor size & $19(11.87)$ & $53(15.27)$ \\
T1 & $40(25.0)$ & $241(69.45)$ \\
T2 & $93(58.13)$ & $47(13.55)$ \\
T3 & $8(5.0)$ & $6(1.73)$ \\
T4 & & \\
Nodal status & $21(13.12)$ & $85(24.49)$ \\
N0 & $38(23.75)$ & $67(150.31)$ \\
N1 & $61(38.13)$ & $45(12.97)$ \\
N2 & $40(25)$ & \\
N3 & &
\end{tabular}

Table 4: TNM staging of all cases

\begin{tabular}{lcc}
\hline TNM stage & $\begin{array}{c}\text { Below 40 yrs } \\
(n=160)(\%)\end{array}$ & $\begin{array}{c}\text { Above } 40 \text { yrs } \\
(\boldsymbol{n}=\mathbf{3 4 7})(\%)\end{array}$ \\
\hline I & $17(11)$ & $52(15)$ \\
II & $55(34)$ & $221(64)$ \\
III & $75(47)$ & $64(18)$ \\
IV & $13(8)$ & $10(3)$ \\
\hline
\end{tabular}

status or seeking treatment outside the state. Younger patients consisted about 122 cases and older patients constituted 215 cases. Among the younger patients, 24 cases $(19.67 \%)$ had succumbed to the disease and 11 cases $(9.02 \%)$ developed locoregional recurrence which included recurrence in the ipsilateral mammary glands, chest wall, or regional lymph nodes. Out of the 215 cases of older patients, 47 cases $(21.86 \%)$ succumbed to the disease and 15 cases $(6.97 \%)$ developed locoregional recurrence. However, statistical analysis between the two groups using Chi-square test showed no statistical significance $(P=0.431)$ [Table 5].

\section{Discussion}

Breast cancer in adolescence and early adulthood is a rare condition. ${ }^{[1]}$ While the median age at presentation is around 63 years in the US and western Europe, the median age at presentation in Lebanon is 48-52 years, similar to Mexico, Saudi Arabia, and the Palestinians; with an age standardized rate (ASR) of 46.7 per 100,000 in 1998. ${ }^{[2]}$ Because of continuing rise in breast cancer incidence, an urgent need to develop strategies for prevention is very much required. Younger age has been generally accepted as an independent adverse prognostic indicator of survival in breast cancer. ${ }^{[13-16]}$ Nevertheless, many reports suggest that the poor outcomes associated with this age group are complicated by several additional factors. ${ }^{[8,17,18]}$ Given the lack of routine screening programs for women younger than 40 years, it is not surprising that women in this age group are more likely to present with a palpable mass and that their tumor tends to be larger and are more likely to have nodal involvement, than tumors detected by screening. ${ }^{\left[{ }^{8,17,19]}\right.}$ It has been determined that underlying tumor pathology such as higher tumor stage, nodal status, and presence of distant metastasis at diagnosis contribute to the worse outcome in breast cancer in women less than 40 years of age. ${ }^{[7,8,20,21]}$ In this study, histopathological analysis showed that the majority of younger women were diagnosed with advanced stage tumors. Invasive ductal carcinoma was common in both groups. We found that 423 cases of the carcinomas were of ductal carcinoma (not otherwise specified [NOS] type), 36 cases of lobular carcinomas, and eight cases were of medullary type. Invasive lobular carcinoma was more common in older women, a finding similar to that published in the literature. ${ }^{[22,23]}$

A large proportion of the patients (85\%) in this study presented with advanced disease. ${ }^{[3]}$ A review of the US National Cancer Database revealed that patients younger than 35 years had more advanced disease at diagnosis and a poorer 5-year survival rate than older premenopausal patients. ${ }^{[24]}$ Similar findings have been reported in the past. ${ }^{[1,5]}$ Many studies across the globe have demonstrated that most of the breast tumors in young women are estrogen receptor (ER) and progesterone receptor (PR) negative indicating a poorer prognosis. ${ }^{[9,17,18]}$ More over the percentage of the known aggressive triple negative (ER, PR, human epidermal 
Table 5: Outcome of patients

\begin{tabular}{|c|c|c|c|c|c|}
\hline \multirow{2}{*}{$\begin{array}{l}\text { Category of } \\
\text { patients }\end{array}$} & \multicolumn{3}{|c|}{ Status $N(\%)$} & \multirow{2}{*}{$\begin{array}{c}\text { Total } \mathbf{N} \\
(\%)\end{array}$} & \multirow{2}{*}{$\begin{array}{c}\text { Pearson Chi-square } \\
\text { ( } P \text { value) }\end{array}$} \\
\hline & Uneventful & Death & $\begin{array}{c}\text { Locoregional } \\
\text { recurrence }\end{array}$ & & \\
\hline Below 40 years & $87(71.31)$ & $24(19.67)$ & $11(9.02)$ & $122(100)$ & 0.431 \\
\hline Above 40 years & $153(71.16)$ & $47(21.86)$ & $15(6.97)$ & $215(100)$ & \\
\hline Total & $240(71.22)$ & $71(21.07)$ & $26(7.71)$ & $337(100)$ & \\
\hline
\end{tabular}

growth factor receptor 2 (HER-2) neu) tumors were reported to be higher in young patients. ${ }^{[25]}$ Younger breast cancer patients have been reported to have germ line BRCA-1 or BRCA-2 mutations in $15-20 \%$ of the cases. ${ }^{[26,27]}$ These mutations are believed to be associated with higher grade, lack of ER receptor, and a higher proliferative rate. ${ }^{[1]}$ Poorer prognosis in younger patients could be due to lack of proper screening, delayed diagnosis, and advanced stage of the disease as also reported by Corpron et al. ${ }^{[28]}$ Data suggests that breast carcinoma in young women have different transcriptomic profile with about 63 genes specific tumors and integrative genomic analysis can pinpoint biomarkers for the detection of disease progression in young women. ${ }^{[29]}$ Assi et al., also highlighted that breast cancer in young women is associated with high grade tumors, hormone receptor negativity, and HER-2 neu overexpression. All these factors finally have a significant negative impact on the prognosis. Thus, more aggressive treatment modalities and follow-up needs to be considered for these groups of patients. ${ }^{[30]}$ The prevalence of triple negative in young women is reported to be low in a study in south India and these groups of patients are likely to be less responsive to the conventional hormonal and targeted antibody treatment. ${ }^{[31]}$ Few modifiable risk factors like rural residence, illiteracy, and low socioeconomic status have been reported. Other factors like late onset of menarche, late onset of menopause, ever oral contraceptive (OCP) usage, breast feeding for 1-2 years, and age of first childbirth between 20-30 years were thought to be protective factors. ${ }^{[32]}$

A larger studies considering the immunomarker status and genetic studies is the need of the hour. This confirms the fact that young females can have breast cancer; hence the need to give serious attention to breast lumps in all females. Late presentation in cancer is common in our environment, but this is more pronounced in young patients with breast cancer.

In conclusion, this study has shown a significant proportion of young females (those less than 40 years) with breast cancer presented with advanced stage. Breast cancer education, free breast cancer detection camps can help in creating awareness on this disease. Proper awareness and screening programs can promote early access to the treatment and thus the mass may give more insight in future.

\section{Acknowledgments}

We would like to thank the Population Based Cancer Registry (ICMR Project), Department of Pathology, RIMS for their support and cooperation of the study.

\section{References}

1. Colleoni M, Rotmensz N, Robertson C, Orlando L, Viale G, Renne G, et al. Very young women ( $<35$ years) with operable breast cancer: Features of disease at presentation. Ann Oncol 2002;13:273-9.

2. El Saghir NS, Seoud M, Khalil MK, Charafeddine M, Salem ZK, Geara FB, et al. Effects of young age at presentation on survival in breast cancer. BMC Cancer 2006; 6:194.

3. Ntekim A, Nufu FT, Campbell OB. Breast cancer in young women in Ibadan, Nigeria. Afr Health Sci 2009; 9:242-6.

4. Kim JK, Kwak BS, Lee JS, Hong SJ, Kim HJ, Son BH, et al. Do very young Korean breast cancer patients have worst outcome? Ann Surg Oncol 2007; 14:3385-91.

5. Swanson GM, Lin CS. Survival patterns among younger women with breast cancer: The effects of age, race, stage, and treatment. J Nat Cancer Inst Monogr 1994; 16:69-77.

6. Brinton LA, Sherman ME, Carreon JD, Anderson WF. Recent trends in breast cancer among younger women in the United States. J Natl Cancer Inst 2008; 100: 1643-8.

7. Chung M, Chang HR, Bland KI, Wanebo HJ. Younger women with breast carcinoma have a poorer prognosis than older women. Cancer 1996;77:97-103.

8. Sidoni A, Cavaliere A, Bellezza G, Scheibel M, Bucciarelli E. Breast cancer in young women: Clinicopathological features and biological specificity. Breast 2003;12:247-50.

9. Gnerlich JL, Deshpande AD, Jeffe DB, Sweet A, White N, Margenthaler JA. Elevated breast cancer mortality in women younger than age 40 years compared with older women is attributed to poorer survival in early-stage disease. J Am Coll Surg 2009;208:341-7.

10. Gajdos C, Tartter PI, Bleiweiss IJ, Bodian C, Brower ST. Stage 0 to stage III breast cancer in young women. J Am Coll Surg 2000; 190:523-9.

11. Maggard MA, O'Connell JB, Lane KE, Liu JH, Etzioni DA, Ko CY. Do young breast cancer patients have worse outcomes? J Surg Res 2003;113:109-13.

12. Kimura M, Yanagita Y, Fujisawa T, Koida T. Study of time-course changes in annual recurrence rates for breast cancer: Data analysis of 2,209 patients for 10 years post-surgery. Breast Cancer Res Treat 2007; 106:407-11.

13. Bonnier P, Romain S, Charpin C, Lejeune C, Tubiana N, Martin PM, et al. Age as a prognostic factor in breast-cancer: Relationship to pathological and biologic features. Int J Cancer 1995;62: 138-44.

14. Xiong QH, Valero V, Kau V, Kau SW, Taylor S, Smith TL, et al. Female patients with breast carcinoma age 30 years and younger have a poor prognosis: The M. D. Anderson Cancer Center Experience. Cancer 2001;92:2523-8.

15. Kollias J, Elston CW, Ellis IO, Robertson JF, Blamey RW. Early-onset breast cancer-histopathological and prognostic considerations. $\mathrm{Br}$ J Cancer 1997;75:1318-23.

16. Yildirim E, Dalgic T, Berberoglu U. Prognostic significance of young age in breast cancer. J Surg Oncol 2000;74:267-72.

17. Bharat A, Aft RL, Gao F, Margenthaler JA. Patient and tumor characteristics associated with increased mortality in young women $(<=40$ Years) with breast cancer. J Surg Oncol 2009; 100:248-51.

18. McAree B, O’Donnell ME, Spence A, Lioe TF, McManus DT, Spence RA. Breast cancer in women under 40 years of age: $A$ series of 57 cases from Northern Ireland. Breast 2010;19:97-104.

19. Leung GM, Thach TQ, Lam TH, Hedley AJ, Fielding R, Yip PS, et al. Trends in breast cancer incidence in Hong Kong between 1973 and 1999: An age-period-cohort analysis. Br J Cancer 2002;87:982-8.

20. Feldman AL, Welch JP. Long-term outcome in women less than 30 years of age with breast cancer. J Surg Oncol 1998;68:193-8. 
21. Livi L, Meattini I, Saieva C, Borghesi S, Scotti V, Petrucci A, et al. The impact of young age on breast cancer outcome. Eur J Surg Oncol 2010;36:639-45.

22. Kwong A, Cheung P, Chan S, Lau S. Breast cancer in Chinese women younger than age 40: Are they different from their older counterparts? World J Surg Onc 2008;32:2554-61.

23. Cristofanilli M, Gonzalez-Angulo A, Sneige N, Kau SW, Broglio K, Theriault RL, et al. Invasive lobular carcinoma classic type: Response to primary chemotherapy and survival outcomes. J Clin Oncol 2005;23:41-8.

24. Winchester DP, Osteen RT, Menck HR. The National cancer data base report on breast carcinoma characteristics and outcome in relation to age. Cancer 1996;78:1838-43.

25. Rakha EA, Reis-Filho JS, Ellis IO. Basal-like breast cancer: A critical review. J Clin Oncol 2008;26:2568-81.

26. Turchetti D, Cortesi L, Federico M, Bertoni C, Mangone L, Ferrari S, et al. BRCA 1 mutations and clinicopathological features in a sample of Italian women with early-onset breast cancer. Eur J Cancer 2000;36:2083-9.

27. Peto J, Collins N, Barfoot R, Seal S, Warren W, Rahman N, et al. Prevalence of BRCA1 and BRCA2 gene mutations in patients with early-onset breast cancer. J Natl Cancer Inst 1999;91:943-9.
28. Corpron CA, Black CT, Singletary SE, Andrassy RJ. Breast cancer in adolescent females. J Pediatr Surg 1995;30:322-4.

29. Colak D, Nofal A, Albakheet A, Nirmal M, Jeprel H, Eldali A, et al. Age-specific gene expression signatures for breast tumors and cross-species conserved potential cancer progression markers in young women. PLoS One 2013;8:e63204.

30. Assi HA, Khoury KE, Dbouk H, Khalil LE, Mouhieddine TH, El Saghir NS. Epidemiology and prognosis of breast cancer in young women. J Thorac Dis 2013;5:S2-8.

31. Rao C, Shetty J, Kishan Prasad HL. Morphological profile and receptor status in breast carcinoma: An institutional study. J Can Res Ther 2013;9:44-9.

32. Das S, Sen S, Mukherjee A, Chakraborty D, Mondal PK. Risk factors of breast cancer among women in eastern India: A tertiary hospital based case control study Asian Pac J Cancer Prev 2012;13:4979-81.

How to cite this article: Thangjam S, Laishram RS, Debnath $\mathrm{K}$ Breast carcinoma in young females below the age of 40 years: $\mathrm{A}$ histopathological perspective. South Asian J Cancer 2014;3:97-100. Source of Support: Nil. Conflict of Interest: None declared.

\section{Announcement}

\section{Indian Cancer Society's - CK Handoo Cancer Research Award}

\section{Rules and Regulations: (Version Date $2^{\text {nd }}$ May 2013)}

There will be one annual award of Rs. 25,000/- This award is for young oncologists to encourage them in their formative years after committing to an oncology career. Following criteria shall be used:

(1) Award based on quality of single most important publication in a peer reviewed medical/ scientific journal where applicant/ nominee is first author.

(2) Completed Age $<40$ years as on 1st April of the year in which applications are invited.

(3) Qualification - currently pursuing onco-training and registered for oncology degree [MD radiotherapy, DM medical oncology or MCh surgical oncology or their equivalent (eg DNB in same subjects)] or in faculty oncology position for not more than 5 years as on 1st April of the year in which applications are invited.

(4) Nominee application to include his/her single best published paper as first author in field of oncology (published in print or electronic form in full text format - abstracts not permitted and accepted articles not permitted if not published).

(5) Nominee must be Indian National

(6) Nominee's work in the publication must have been carried out in India

(7) Nominee's work in the publication must be related to Cancer

(8) Applications can be made by nominees themselves of by any other reputed oncologist. Applications/ Nominations should be sent to Managing Trustee, Indian Cancer Society, 74 Jerbai Wadia Road, Bhoiwada, Parel East, Mumbai 400012. The envelope should be clearly marked "CK Handoo Cancer Research Award Application". Applications can also be sent by email. For complete details, rules and regulations please contact ICS or access www.indiancancersociety.org.

(9) Winners will have to be personally present at the designated function to receive the awards. Those who cannot be present shall forfeit the award.

(10)The decision of Indian Cancer Society regarding these awards is final and binding on all applicants. Last date for receiving applications is 1st June 2014.

Advance application can be sent to Shankar@indiancancersociety.org 